\title{
AGE-RELATED MORPHOMETRIC CHARACTERISTICS OF REMODELING OF ARTERIAL BED OF HIND LIMBS IN WHITE RATS WITH EXPERIMENTAL HYPERCHOLESTEROLEMIA
}

\author{
I. I. Yuryk, Ya. Ya. Bodnar, V. D. Voloshyn, Ya. I. Yuryk \\ I. HORBACHEVSKY TERNOPIL STATE MEDICAL UNIVERSITY, TERNOPIL, UKRAINE
}

Background. The human organism is constantly affected by metabolic risk factors. All of them for a long time are asymptomatic and often form in early childhood long before clinical manifestations. However, morphogenesis and morphofunctional features of age-related structural changes in blood vessels of different sites are poorly studied.

Objective. To evaluate the morphometric characteristics of arterial bed remodeling of hind limbs in white rats of PRA and RA with experimentally induced hypercholesterolemia.

Methods. The tissues biopsies from femoral, knee and shin areas were studied by means of histological and morphometric methods.

Results. Experimental hypercholesterolemia caused remodeling of vessels with increasing thickness of medial and endothelial layer of vessels in the investigated parts of the rats' body. In this case, the external diameter of vessels increased only in femoral area in the reproductive group of rats. In the group of pre-productive animals, the external diameter of the vessels studied was more or less unaffected. Thus, increased thickness of intima and media led to a decrease in arteries capacity. The depth of vascular lesions and the decrease in functional capacity of blood vessels were directly proportional to the duration of the experiment. In the group of reproductive rats, the changes in vascular bed were more evident.

Conclusions. Objective study of the processes allows providing a scientific basis for further research and understanding of the pathomorphism of vascular diseases in humans.

KEY WORDS: hypercholesterolemia; arteries; remodelling; morphometria.

\section{Introduction}

Cardiovascular diseases take the first place in the population mortality rate of the most countries of the world and are characterized by the increase in their prevalence rates, including those at young able-bodied age [1, 2]. According to state statistics [3], in Ukraine over the past 10 years the prevalence of obesity among adolescents (15-17 years) per 1000 children population has increased in 2.5 times [3]. The human and animal organism is constantly affected by metabolic risk factors: insulin resistance, hyperinsulinemia, dyslipidemia, arterial hypertension, abdominal obesity, hyperuricemia are the most significant. All of them are asymptomatic for a long time and often form in early childhood long before clinical manifesta-

Corresponding author: Ihor Yuryk, Department of Pathoanatomy with Forensic Medicine and Sectional Course, I. Horbachevsky Ternopil State Medical University, 12 Ruska Str., Ternopil, Ukraine, 46008

Phone number: +380352525844

E-mail: juryk@tdmu.edu.ua tions [4]. One of the first reactions to the toxic effects of metabolites are structural changes of vessels. However, morphogenesis and morphofunctional features of age-related structural changes in blood vessels of different sites are poorly studied. In the literature the established data is interpreted ambiguously. So, defining the morphometric rearrangement of arteries of femoral, knee and shin area of hind limbs in rats of pre-reproductive (PRA) and reproductive age (RA) with hypercholesterolemia $(\mathrm{HH})$ is very important. So, the aim of the research was to evaluate the features of morphometric characteristics of remodeling of arterial bed of hind limbs in white rats of PRA and RA with experimentally induced hypercholesterolemia.

\section{Methods}

Studies were performed by means of 64 white rats. The experimental group consisted of 48 animals with biochemically confirmed hypercholesterolemia. They were divided into 
2 groups: the first - 24 rats, 2-3 months-old in age, weighing 150-170 grams; and the second 24 rats aged 10-11 months, weighing 230 250 grams. The control group consisted of rats aged 2-3 and 10-11 months comprising 8 animals in each subgroup. Hypercholesterolemia was modeled by feeding cholesterol at a dose of $0.5 \mathrm{~g} / \mathrm{kg}$ with warmed vegetable oil. To suppress thyroid function, Mercazolil was used at a dose of $10 \mathrm{mg} / \mathrm{kg}[5,6]$. This mixture was administered by means of an intragastric probe.

The level of cholesterolemia was determined by a biochemical method by means of a semiautomatic biochemical analyzer Humalyzer 2000 (Germany) using a standard set of reagents and instructions for their use, Human (Germany).

The biopsies of the tissues of femoral, knee and shin areas were fixed in a 10\% neutral formalin solution and, according to a standard procedure, were sealed with paraffin. The dewaxed microtome sections were stained with hematoxylin and eosin, resorcin-fuchsin by Weigert and van Gieson, fuchsin Hart, iron hematoxylin by Heidenhain and alcian blue. During histological preparations for morphometry, the microscopes SEOSCAN, MBI-15 were used. The image from the microscopes was displayed on a computer monitor using the programs VISION Color CCD Camera and InterVideoWinDVR. To determine the size of tissue structures of vascular wall, the images of histological sections were analysed using the computer programs VideoTest-5.0, Kaare Image Base. The external diameter (ED) of arteries, the internal diameter (ID) of arteries, the thickness of medial (TM), the thickness of intima (TI), the resistance index of bandwidth capacity of arteries (RIBCA) were determined. The latter was calculated as the ratio of wall area of vessel to the area of its lumen in percent [7]. Laboratory rats were taken out from the experiment by bleeding after intraperitoneal injection of sodium thiopental at a dose of $50 \mathrm{mg} / \mathrm{kg}$ of body weight in 15, 30 and 45 days.

The rats were kept and all experiments were carried out in compliance with the European Convention for the Protection of Vertebrate Animals used for Experimental and Other Scientific Purposes (Strasbourg, 1986), the General Ethical Principles of Experiments on Animals adopted by the First National Congress on Bioethics (Kiev, 2001). ), the Helsinki Declaration of the World Medical Association (2000), the Order of the Ministry of Health of Ukraine No. 281 from January 11, 2000.

\section{Results}

The level of cholesterolemia in the rats of pre-reproductive age with experimental hypercholesterolemia in 15 days was $(2.15 \pm 0.03) \mathrm{mmol} / \mathrm{l}$, and in the rats of reproductive age $-(2.20 \pm 0.03) \mathrm{mmol} / \mathrm{l}$. In 30 days the level of cholesterolemia in the PRA rats was $(2.68 \pm 0.04) \mathrm{mmol} / \mathrm{l}$ and in the RA rats $(2.82 \pm 0.03) \mathrm{mmol} / \mathrm{l}$. In 45 days the cholesterolemia level in the PRA rats was $(2.83 \pm 0.05) \mathrm{mmol} / \mathrm{l}$ and in the RA rats $-(3.03 \pm 0.03) \mathrm{mmol} / \mathrm{l}$. In the intact rats group, the level of cholesterolemia was $(1.80 \pm 0.04) \mathrm{mmol} / \mathrm{l}$ in the PRA animals and $(1.37 \pm 0.04) \mathrm{mmol} / \mathrm{l}$ in the RA animals.

Analysis of the obtained morphometric indices in the animals of PRA and RA with experimental $\mathrm{HH}$ proved that they had a tendency to increase in comparison with the same parameters in the animals of intact group. In the rats of reproductive age, the structural changes are presented in Table 1.

Thus, the external diameter of femoral artery of the intact animals of reproductive age increased from $(525.41 \pm 2.70) \mu \mathrm{m}$ to $(534.84 \pm 1.98) \mu \mathrm{m}$, which was $1.8 \%$ at $p<0.01$ in 45 days of the experiment. The internal diameter of femoral artery decreased by $4.65 \%$ in 30 days and by $6.32 \%$ in 45 days of the research $(p<0.001)$. TTM of femoral artery increased from $(100.04 \pm 0.69) \mu \mathrm{m}$ to $(114.44 \pm 0.76) \mu \mathrm{m}$, which was $14.39 \%$ in 45 days of the experiment $(p<0.001)$.

The index of resistance to the femoral artery capacity gradually increased from $(161.04 \pm 1.50)$ to $(195.86 \pm 2.85) \%$ in 30 days of the experiment and to $(205.88 \pm 2,21) \%$ in 45 days $(p<0.001)$ and was higher by $21,62 \%$ and $27,84 \%$ respectively (Fig. 1).

The external diameter of popliteal artery and tibia artery in the rats of reproductive age was more or less unchanged till the end of the experiment. The internal diameter of popliteal artery decreased in 30 days of the experiment by $4.33 \%$ and in 45 days - by $5.55 \%(p<0.01)$. The TTM of popliteal artery increased from $(81.29 \pm 0.37) \mu \mathrm{m}$ to $(83.35 \pm 0.74) \mu \mathrm{m}$ in 15 days $(2.6 \%(p<0.05))$, to $(89.11 \pm 1.12) \mu \mathrm{m}$ in 30 days $(9.6 \%(p<0.001))$, and up to $(90.69 \pm 0.94) \mu \mathrm{m}$ $(11.56 \%(p<0.001))$ in 45 days of the experiment. Bandwidth resistance index of popliteal artery increased by $5.56 \%$ in 15 days $(p<0.01)$, in 30 days - by $20.55 \%(p<0.001)$, and in 45 days - by $24.53 \%(p<0.001)$.

The internal diameter of artery of tibial area in the reproductive age animals in 15 days decreased by $2.75 \%(p<0.05)$, in 30 days - by 
Table 1. Morphometric indices of arteries of hind limbs of the rats of reproductive age with experimental hypercholesterolemia

\begin{tabular}{|c|c|c|c|c|}
\hline \multirow{2}{*}{$\begin{array}{l}\text { Time of the } \\
\text { experiment }\end{array}$} & \multirow[b]{2}{*}{ Area studied } & \multicolumn{3}{|c|}{ Parameters } \\
\hline & & $\mathrm{ED}, \mu \mathrm{m}$ & ID, $\mu \mathrm{m}$ & TTM, $\mu \mathrm{m}$ \\
\hline \multirow{3}{*}{$\begin{array}{l}\text { Intact } \\
\text { animals }\end{array}$} & Femoral artery & $525.41 \pm 2.70$ & $325.32 \pm 1.98$ & $100.04 \pm 0.69$ \\
\hline & Popliteal artery & $416.69 \pm 1.50$ & $254.12 \pm 0.97$ & $81.29 \pm 0.37$ \\
\hline & Tibia artery & $139.17 \pm 0.70$ & $83.18 \pm 0.37$ & $28.00 \pm 0.19$ \\
\hline \multirow{3}{*}{$\begin{array}{l}\text { Within } \\
15 \text { days }\end{array}$} & Femoral artery & $533.38 \pm 1.70 *$ & $321.17 \pm 2.52$ & $106.11 \pm 1.01 * * *$ \\
\hline & Popliteal artery & $416.91 \pm 1.90$ & $250.21 \pm 1.71$ & $83.35 \pm 0.74^{*}$ \\
\hline & Tibia artery & $139.45 \pm 1.21$ & $80.90 \pm 1.06 *$ & $29.27 \pm 0.32 * *$ \\
\hline \multirow{3}{*}{$\begin{array}{l}\text { Within } \\
30 \text { days }\end{array}$} & Femoral artery & $533.15 \pm 2.75 *$ & $310.23 \pm 1.97 * * *$ & $111.46 \pm 1.02 * * *$ \\
\hline & Popliteal artery & $419.65 \pm 2.26$ & $241.44 \pm 2.13 * * *$ & $89.11 \pm 1.12 * * *$ \\
\hline & Tibia artery & $140.26 \pm 1.32$ & $79.71 \pm 1.06 * *$ & $30.27 \pm 0.43 * * \star$ \\
\hline \multirow{3}{*}{$\begin{array}{l}\text { Within } \\
45 \text { days }\end{array}$} & Femoral artery & $534.84 \pm 1.98 * *$ & $305.96 \pm 1.41 * * *$ & $114.44 \pm 0.76 * * *$ \\
\hline & Popliteal artery & $419.95 \pm 2.37$ & $238.57 \pm 1.43 * * *$ & $90.69 \pm 0.94 * * *$ \\
\hline & Tibia artery & $140.73 \pm 1.37$ & $79.57 \pm 1.13 * *$ & $30.58 \pm 0.66 * * *$ \\
\hline
\end{tabular}

Notes: * - p<0.05; ** - p<0.01; *** - p<0.001

ED - external diameter; ID - internal diameter; TTM - thickness of tunica media.

$4.2 \%(p<0.001)$ and in 45 days of the study - by $4.4 \%(p<0.001)$. Statistical significance $(p<0.01)$ of TTM arteries of tibial area increased in 15 days of the experiment, and in 45 days of the experiment it was by $9.2 \%$ higher $(\mathrm{p}<0.001)$. The ARI in tibial area increased from $(179.93 \pm 0.85) \%$ to $(216.80 \pm 7.92) \%$ in 45 days $(\mathrm{p}<0.001)$ and was higher by $20.49 \%$.

The tunica intima (TI) in the rats of reproductive age (RA) in 15 days of the experiment was significant only in the knee area $(+4.8 \%$ $(p<0.05))$. Morphometric indices of other regions during this period were unreliable. After 30 days, the TI of femoral artery in the reproductive animals increased by $7.78 \%(p<0.001)$, and in 45 days - by $8.83 \%(p<0.001)$. In the popliteal region the TI increased by $8.00 \%$ (in 30 days) and by $10.45 \%(p<0.001)$ in 45 days of the experiment. The values of TI of tibial area increased by $8.62 \%$ in 30 days and by $8.95 \%$ $(p<0.001)$ in 45 days.

In the animals of pre-reproductive age (PRA), the morphometric parameters were similar, although somewhat reduced (Table 2). Thus, the external diameter of femoral artery was more or less unchanged during the study. The internal diameter of femoral artery decreased by $2 \%$ in 15 days $(p<0.05)$, by $5.44 \%$ in 30 days and by $670 \%$ in 45 days of the study $(p<0.001)$.

The parameters of TM of femoral artery increased in 30 days by $8.93 \%$ from $(69.53 \pm 0.85) \mu \mathrm{m}$ to $(75.74 \pm 1.15) \mu \mathrm{m}(p<0.001)$; In 45 days it increased by $11.11 \%$ to $(77.26 \pm 0.74) \mu \mathrm{m}(p<0.001)$. The IHSS of femoral artery gradually increased in 15 days by $6.4 \%$ from $(164.23 \pm 2.58)$ to $(174.72 \pm 2.61) \%(p<0.01)$, in 30 days of the experiment - by $19.79 \%$ to

Table 2. Morphometric parameters of arteries of hind limbs of the pre-reproductive age rats with experimental hypercholesterolemia, $(\mathrm{M} \pm \mathrm{m})$

\begin{tabular}{|c|c|c|c|c|}
\hline \multirow{2}{*}{$\begin{array}{l}\text { Time of the } \\
\text { experiment }\end{array}$} & \multirow{2}{*}{ Area studied } & \multicolumn{3}{|c|}{ Parameters } \\
\hline & & $\mathrm{ED}, \mu \mathrm{m}$ & ID, $\mu \mathrm{m}$ & TTM, $\mu \mathrm{m}$ \\
\hline \multirow{3}{*}{$\begin{array}{c}\text { Intact } \\
\text { animals }\end{array}$} & Femoral artery & $361.66 \pm 2.18$ & $222.60 \pm 1.10$ & $69.53 \pm 0.85$ \\
\hline & Popliteal artery & $295.09 \pm 1.66$ & $179.79 \pm 1.43$ & $57.65 \pm 0.79$ \\
\hline & Tibia artery & $94.83 \pm 0.87$ & $56.54 \pm 0.47$ & $19.15 \pm 0.29$ \\
\hline \multirow{3}{*}{$\begin{array}{l}\text { Within } \\
15 \text { days }\end{array}$} & Femoral artery & $361.50 \pm 2.48$ & $218.25 \pm 1.54 *$ & $71.62 \pm 0.81$ \\
\hline & \begin{tabular}{|l|} 
Popliteal artery \\
\end{tabular} & $295.69 \pm 1.66$ & $174.59 \pm 1.41$ * & $60.55 \pm 1.41 *$ \\
\hline & \begin{tabular}{|l|} 
Tibia artery \\
\end{tabular} & $95.01 \pm 0.63$ & $55.24 \pm 0.64$ & $19.88 \pm 0.23$ \\
\hline \multirow{3}{*}{$\begin{array}{l}\text { Within } \\
30 \text { days }\end{array}$} & Femoral artery & $362.00 \pm 2.44$ & $210.51 \pm 1.53 * \star \star *$ & $75.74 \pm 1.15 * * *$ \\
\hline & Popliteal artery & $296.03 \pm 1.75$ & $170.02 \pm 1.32 * \star \star$ & $63.00 \pm 0.84 * * *$ \\
\hline & Tibia artery & $95.28 \pm 0.96$ & $54.21 \pm 0.53 * *$ & $20.53 \pm 0.32 * *$ \\
\hline \multirow{3}{*}{$\begin{array}{l}\text { Within } \\
45 \text { days }\end{array}$} & Femoral artery & $362.10 \pm 2.25$ & $207.70 \pm 1.57 * \star \star *$ & $77.26 \pm 0.74$ *** \\
\hline & \begin{tabular}{|l|} 
Popliteal artery \\
\end{tabular} & $296.83 \pm 1.84$ & $169.98 \pm 1.46 * * *$ & $63.43 \pm 0.68 * * *$ \\
\hline & Tibia artery & $95.77 \pm 0.83$ & $54.04 \pm 0.39 * * *$ & $20.87 \pm 0.29 * * *$ \\
\hline
\end{tabular}

Notes: * $-p<0.05 ; * *-p<0.01 ; * * *-p<0.001$ 
$(196.74 \pm 4.48) \%(p<0.001)$ and in 45 days - by $24,67 \%$ to $(204.76 \pm 3,10) \%(p<0.001)$ (Fig. 2$)$.

The external diameter of popliteal artery and tibial artery in the PRA rats, (and in the RA animals) didn't change just about till the end of the experiment. The internal diameter of popliteal artery decreased in 15 days by $2.9 \%$ $(p<0.05)$, in 30 days - by $5.44 \%$, in 45 days - by $5.46 \%(p<0.001)$. The TM of popliteal artery increased in 15 days by $5 \%(p<0.05)$, in 30 days by $9.28 \%(p<0.001)$ and in 45 days of the experiment - by $10.02 \%$. The RIBCA of popliteal artery increased by $10.33 \%$ in 15 days ( $p<0.01$ ), in 30 days - by $19.95 \%$, and in 45 days - by $20.81 \%(p<0.001)$. The internal diameter of artery of tibial area decreased in 15 days of the study by $2.30 \%$, in 30 days - by $4.11 \%(p<0.01)$, and in 45 days - by $4.43 \%(p<0.001)$. The TM of artery of tibial region increased by $7.26 \%$ $(p<0.01)$ in 30 days of the experiment, and in 45 days of the experiment it increased by $8.98 \%$ $(p<0.001)$. The RIBCA of tibial region arteries increased in 45 days of the experiment from $(181.82 \pm 3.45)$ to $(214.43 \pm 3.33) \%(p<0.001)$ and was by $17.93 \%$ higher than the control.

The thickness of intima of arteries in the PRA rats with experimental hypercholesterolemia increased a bit less than in the rats of RA. In 15 days of the experiment, the thickening of the intima was not reliable at all levels of the study. In 30 days, the TI of femoral artery increased by $6.90 \%(p<0.01)$, and in 45 days - by $7.63 \%(p<0.001)$; the TI of popliteal artery in- creased in 30 days by $7.69 \%(p<0.01)$ and in 45 days - by $9.61 \%(p<0.001)$; the increase of TI of tibial artery was $6.58 \%(p<0.01)$ in 30 days and $8.40 \%(p<0.001)$ in 45 days of the experiment.

\section{Discussion}

Arteries remodeling is initiated as an adaptive process in response to altered circulatory conditions or to the influence of any humoral agents. The arterial vessels are shaped throughout life: the walls of vessels thicken, their rigidity increases. The endothelium dysfunction and its increased permeability are indicators of arteries aging. These negative processes result in an enhanced synthesis of vasoconstrictor substances: angiotensin II and endothelin. At the same time, vasodilation development factors: nitric oxide, prostacyclin decrease, are manifested $[8,9]$. In conditions of insufficient amount of nitric oxide, the endothelium of vessels cannot fulfil its inherent functions, and the decrease in the amount of $\mathrm{NO}$ in the vessels is the cause of atherosclerosis, other cardiovascular diseases and one of the first signs of aging of vascular bed. Intima diffusely thickens due to the aging of arteries that is caused by the accumulation of extracellular matrix proteins, smooth myocytes, collagen, glycosaminoglycans in it. These factors contribute to the enhanced adhesion of monocytes to the luminal surface of endothelium and are one of the stages of atherosclerotic plaque formation in arteries. There is evidence that vessel intima

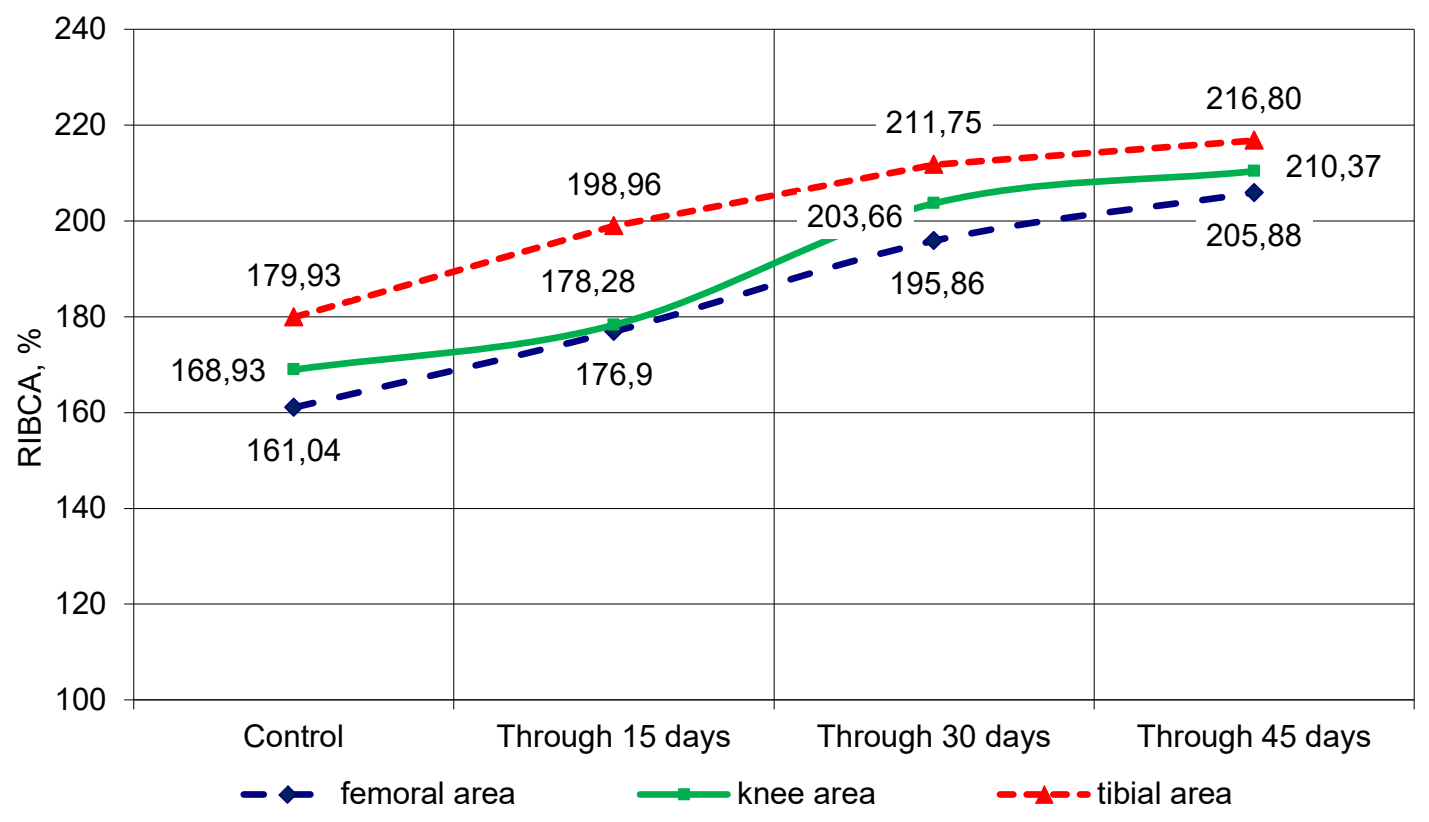

Fig. 1. The resistance index of the bandwidth capacity of arteries (RIBCA) of hind limbs in the rats of reproductive age with experimental hypercholesterolemia 


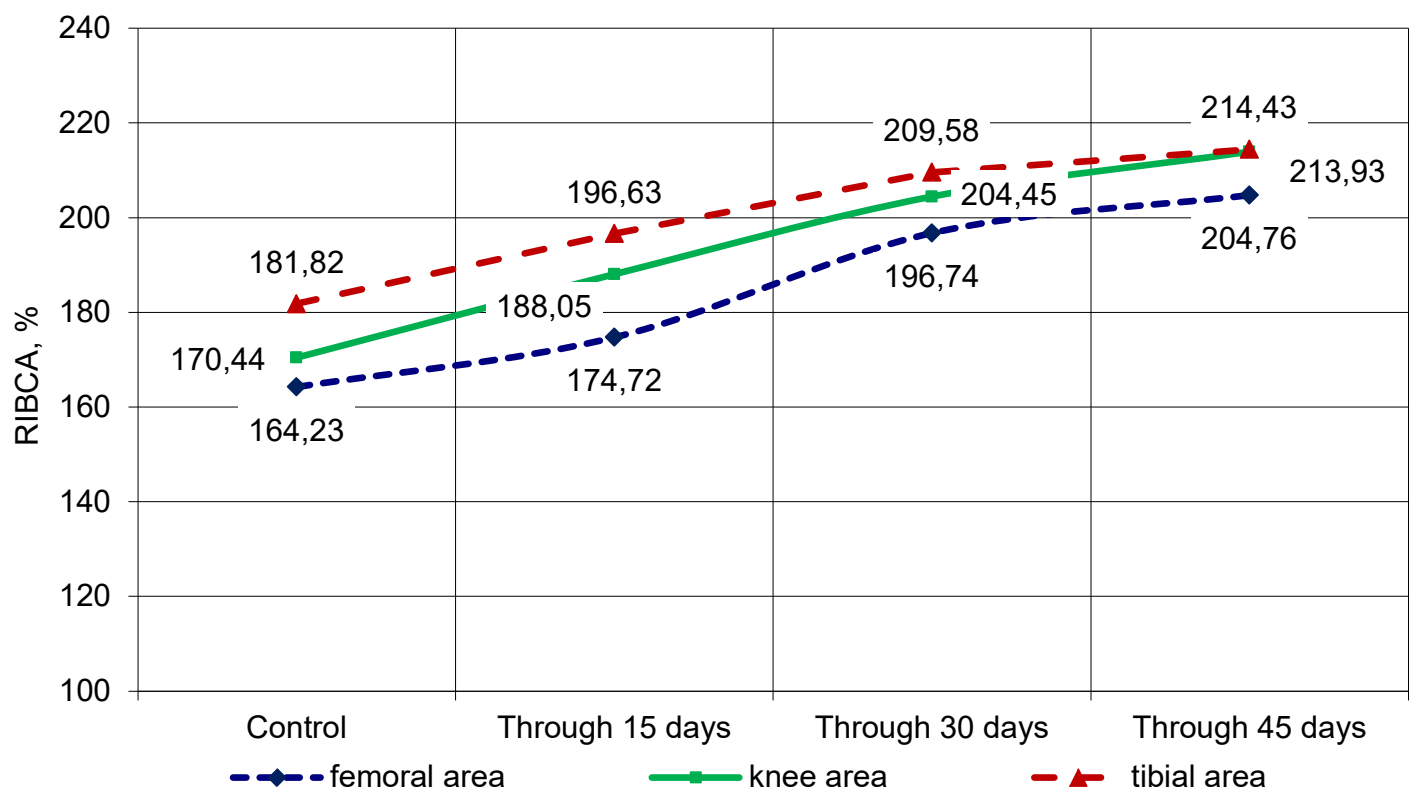

Fig. 2. The resistance index of bandwidth capacity of arteries (RIBCA) of hind limbs in the rats of pre-production age with experimental hypercholesterolemia

thickens in 2-3 times for the period of from 20 to 90 years old $[10,11]$.

The Proteins of extracellular matrix of the middle shell of arteries undergo significant structural and functional changes in aging. In the vessels there is an excessive deposition of calcium, transition of smooth myocytes from media into intima. Elastin of arteries is thinned that is characterized by fragmentation phenomena under the influence of matrix metalloproteinases and transforming growth factor-TGF- $\beta$ $[12,13]$. In contrast, the collagen protein synthesis is promoted with the assistance of angiotensin II, which increases the rigidity of collagen itself and vascular wall [14, 15]. Smooth myocytes in the intima of vessels are characterized by increased proliferation. This promotes the adhesion of blood cells to the endothelium of arterial vessels, thickening of intima, increasing its stiffness and development of atherosclerosis [16]. Morphometric indices in animals with hypercholesterolemia prove that hypercholesterolemia was accompanied by remodeling of predominantly femoral and popliteal arteries that was severe in the animals of reproductive age.

\section{Conclusions}

Experimental hypercholesterolemia in the rats of reproductive age was accompanied by remodeling of predominantly femoral and popliteal arteries. It should be noted that the intensity of these changes in the arteries of large caliber in the animals of pre-reproductive age was lower than in the animals of reproductive group, and remodeling of lower leg arteries was more significant in the animals of reproductive age.

\section{References}

1. Go AS, Mozaffarian D, Roger VL, Benjamin EJ, Berry JD, Borden WB, et al. Executive Summary: heart disease and stroke statistics - 2013 update. A report from the American Heart Association. Circulation. 2013;127:143-52.

2. Roger VL, Go AS, Lloyd-Jones DM, Benjamin EJ, Berry JD, Borden WB, et al. Executive Summary: heart disease and stroke statistics - 2012 update. Circulation. 2012 Jun 5;125(22):188-97.

3. Tokarchuk NI, Timchuk EV. Overweight in young children is a factor of risk of illness in the future (review of literature). Modern Pediatrics. 2009; 6(28):54-6. 
4. Halpern AL, Mancini MC, Magalhaes ME, Fisberg $M$, Radominski R, Bertolami MC, et al. Metabolic syndrome, dyslipidemia, hypertension and type 2 diabetes in youth: from diagnosis to treatment. Diabetol. Metab. Syndr. 2010;2:55-75. https://doi. org/10.1186/1758-5996-2-55.

5. Polyakov LM, Lushnykova EL, Nepomnyashchykh LM, Russkykh HS, Byushkyna NH, Klynnykova $\mathrm{MH}$, et al. Indicators of lipid metabolism and protein composition of blood plasma lipoproteins of hypothyroid rats at experimental hypercholesterolemia. Fundamental research. 2014;(10):342-5.

6. Mikhail GS, Alshammari SM, Alenezi MY, Mansour M, Khalil NA. Increased atherogenic low-density lipoprotein cholesterol in untreated subclinical hypothyroidism. Endocr. Pract. 2008;14(5):570-5.

7. Avtandilov HH. Medical morphometry. Moscow: Medicina; 1990.

8. Klinkova EV, Otteva EN, Harbuzova OH, Isakova VN, Bandurko EV. Assessment of arterial rigidity in patients with gout and arterial hypertension.. Scientific and practical rheumatology. 2010;(6):40-5.

9. Safar M, Wang M, Lakatta EG. Central arterial aging: humans to molecules. Handbook of hypertension: arterial stiffness in hypertension. Amsterdam: Elsevier. 2006.

10. Palluy O, Morliere L, Gris JC, Bonne C, Modat G. Hypoxia/reoxygenation stimulates endothelium to promote neutrophil adhesion. Free Radic.
Biol. Med. 1992;13(1):21-30. https://DOI: 10.1016/ 0891-5849(92)90161-9.

11. Orlandi A, Marcellini M, Spagnoli LG. Aging influences development and progression of early aortic atherosclerotic lesions in cholesterol-fed rabbits. Arterioscler Thromb Vasc Biol. 2000;20(4): 1123-36.

12. Li Z, Froehlich J, Galis ZS, Lakatta EG. Increased Expression of Matrix Metalloproteinase- 2 in the Thickened Intima of Aged Rats. Hypertension. 1999;33(1):116-23.

13. Risinger GM Jr, Updike DL, Bullen EC, Tomasek JJ, Howard EW. TGF- suppresses the upregulation of MMP-2 by vascular smooth muscle cells in response to PDGF-BB. Am J Physiol Cell Physiol. 2010 Jan; 2010;298(1):191-201. https://doi:10.1152/ajpcell. 00417.2008.

14. Konova E, Baydanoff S, Atanasova M, Velkova A. Age-related changes in the glycation of human aortic elastin. Exp Gerontol. 2004;39(2):249-54. https://DOI: 10.1016/j.exger.2003.10.003.

15. Zieman SJ. Mechanisms, Pathophysiology and Therapy of Arterial Stiffness. Arterioscler Thromb Vasc Biol. 2005;25(5):932-43. https://DOI: 10.1161/01. ATV.0000160548.78317.29

16. Strazhesko ID, Akasheva DU, Dudinskaya YeN, Tkacheva ON. Aging of blood vessels: basic signs and mechanisms. Cardiovascular therapy and prevention. 2012;11(4):93-100. 